- FINANSE I PRAWO FINANSOWE.

- Journal of Finance and Financial Law •

Grudzień/December 2019 • vol. 4(24): 67-84

http://dx.doi.org/10.18778/2391-6478.4.24.05

\title{
SPECYFIKA I KONKURENCYJNOŚĆ BANKÓW SPÓŁDZIELCZYCH W POLSCE
}

Klaudia Musialik

Wydział Zarządzania, Uniwersytet Łódzki

\begin{abstract}
Streszczenie
Bankowość spółdzielcza postrzegana jest głównie jako mało nowoczesna bankowość tradycyjna o charakterze lokalnym. W związku z tym podjęto taki, a nie inny temat artykułu, by pokazać jego konkurencyjność $w$ różnych obszarach. Celem artykułu jest pokazanie różnic i podobieństw między bankami spółdzielczymi a bankami komercyjnymi i SKOK-ami. Przedstawiono również wybrane dane statystyczne dotyczące tych instytucji. Ponadto, zamierzeniem autorki artykułu było zbadanie stopnia konkurencyjności bankowości spółdzielczej. Autorka w artykule weryfikowała hipotezę badawczą, że najbardziej konkurencyjnymi spośród banków spółdzielczych, banków komercyjnych, jak i SKOK-ów są banki spółdzielcze, co jest oceniane przez klientów w perspektywie ich zadowolenia. Badanie przeprowadzono za pomocą kwestionariusza ankiety. Ukazało ono, że w ocenie klientów występują zarówno dobrze prosperujące obszary instytucji finansowych, jak i te, które wymagają poprawy.
\end{abstract}

Słowa kluczowe: bank spółdzielczy, bank komercyjny, SKOK, konkurencyjność, zadowolenie, usługi finansowe.

JEL Class: G21, G23. 


\section{WPROWADZENIE}

W obecnych czasach na rynku finansowym dochodzi do szeroko pojętej konkurencji między instytucjami finansowymi. Istotą konkurencji jest pozyskanie klienta oraz nawiązanie z nim trwałej relacji. Jest to możliwe poprzez sprostanie jego oczekiwaniom oraz zapewnienie mu satysfakcji korzystania z oferowanych usług. Zarówno banki komercyjne, banki spółdzielcze, jak i SKOK-i charakteryzują się pewnymi indywidualnymi cechami, które wykorzystują by zachęcić klientów do swoich usług.

Konkurencyjność banków spółdzielczych jest ciekawym, dość kontrowersyjnym zagadnieniem. Jest to związane z tym, że bankowość spółdzielcza postrzegana jest głównie jako mało nowoczesna bankowość tradycyjna o charakterze lokalnym. W związku z tym podjęto taki, a nie inny temat artykułu, by bliżej przyjrzeć się specyfice tego sektora i pokazać jego konkurencyjność w różnych obszarach, chociażby w perspektywie zadowolenia klientów tych instytucji, a nie przedstawionych stereotypów.

Celem artykułu jest przedstawienie różnic i podobieństw między bankami spółdzielczymi a bankami komercyjnymi i spółdzielczymi kasami oszczędnościowo-kredytowymi. Ponadto zamierzeniem autorki artykułu jest pokazanie wybranych danych statystycznych instytucji finansowych oraz zbadanie poziomu konkurencyjności banków spółdzielczych na tle banków komercyjnych oraz spółdzielczych kas oszczędnościowo-kredytowych.

W tym celu autorka artykułu weryfikowała hipotezę badawcza mówiącą o tym, że najbardziej konkurencyjnymi spośród banków spółdzielczych, banków komercyjnych, jak i SKOK-ów są banki spółdzielcze, co jest oceniane przez klientów w perspektywie ich zadowolenia. Główny problem badawczy obejmuje bardziej szczegółowe zagadnienia takie jak:

- zakres korzystania z usług finansowych,

- ocena obszarów funkcjonowania instytucji finansowych,

- aspekty funkcjonalności bankowości elektronicznej i mobilnej,

- wiedza z zakresu akcji promocyjnych i marketingowych.

Artykuł składa się z trzech części.

Pierwsza część została poświęcona porównaniu banków spółdzielczych z bankami komercyjnymi oraz spółdzielczymi kasami oszczędnościowo-kredytowymi. Pod uwagę wzięto m.in. cel działania, przepisy prawne, wymagane fundusze własne czy formę organizacyjno-prawną.

$W$ drugiej cześsci przedstawiono informacje statystyczne dotyczące liczby placówek, instytucji oraz zatrudniania $\mathrm{w}$ omawianych instytucjach finansowych w latach 2014-2018.

$W$ trzeciej części podjęto próbę oszacowania zadowolenia klientów z usługi działania instytucji finansowych. Przeprowadzono badanie, na podstawie którego 
określono zainteresowanie usługami finansowymi oraz przeanalizowano poszczególne obszary działania instytucji finansowych w celu określenia stopnia ich konkurencyjności. Badanie ankietowe zostało przeprowadzone w lutym 2019 roku.

\section{BANKI SPÓŁDZIELCZE W KONKURENCYJNYM OTOCZENIU}

\subsection{Podobieństwa i różnice między bankami spółdzielczymi a SKOK-ami}

W Polsce, na dzień dzisiejszy istnieją dwa rodzaje spółdzielni oszczędnościowo-kredytowych, którymi są banki spółdzielcze oraz spółdzielcze kasy oszczędnościowo-kredytowe. Instytucje te są do siebie podobne pod wieloma względami, ale też znacząco się różnią. Podobieństwa oraz różnice między nimi najbardziej uwidaczniają się w aspekcie historycznym, prawnym, uwarunkowań potencjału, kondycji finansowej oraz oferty [Orzeszko 2014: 130-131].

Jeżeli chodzi o podobieństwa na podłożu historycznym, można zauważyć wspólne pochodzenie obydwu instytucji. Ich powstanie sięga okresu średniowiecza. W tym okresie tworzono pierwsze przedspółdzielcze zakłady, oferujące usługi pożyczkowe lub pożyczkowo-oszczędnościowe. Różnic można upatrywać w samej formie funkcjonowania instytucji. Spółdzielnie Schulzego zyskały cechy charakterystyczne dla instytucji komercyjnych, przekształcając się w obecnie funkcjonujące banki spółdzielcze. Spółdzielnie Raiffeisena z kolei przerodziły się $\mathrm{w}$ aktualnie działające spółdzielcze kasy oszczędnościowo-kredytowe [Orzeszko 2014: 132-134].

Banki spółdzielcze oraz kasy oszczędnościowo-kredytowe działają według określonych norm prawnych. Funkcjonowanie SKOK-ów określa ustawa z 2009 r. [Ustawa z dnia 5 listopada 2009 r..., Dz.U. 2018, poz. 2386] oraz w przypadku nieregulowanych w niej aspektów, tak jak w przypadku banków spółdzielczych - ustawa Prawo spółdzielcze [Ustawa z dnia 16 września 1982 r..., Dz.U. 2018, poz. 1285]. Niektóre akty prawne regulują działalność obydwu instytucji o charakterze spółdzielczym. Jest to np. ustawa o podatku dochodowym od osób prawnych [Ustawa z dnia 15 lutego 1992 r..., Dz.U. 2019, poz. 865]. Banki spółdzielcze są objęte $\mathrm{w}$ szerszym stopniu regulacjami prawa unijnego niż SKOK-i. Przykładem tego jest obowiązek stosowania się banków spółdzielczych do Dyrektywy Parlamentu Europejskiego i Rady [Dyrektywa Parlamentu Europejskiego i Rady 2013/36/UE z 26 czerwca 2013 r...], gdzie spółdzielcze kasy oszczędnościowo-kredytowe takiego obowiązku nie mają [Orzeszko 2014: 142-146].

Biorąc pod uwagę samą istotę działania przedstawionych instytucji zauważalne są istotne podobieństwa. Zarówno banki spółdzielcze, jak i SKOK-i są zobowiązane funkcjonować zgodnie z zasadami spółdzielczymi: dobrowolnego 
i powszechnie dostępnego członkostwa, demokratycznej kontroli, ekonomicznego uczestnictwa członków, samorządności i niezależności, kształcenia, szkolenia i informowania, współpracy między spółdzielniami oraz troski o społeczność lokalną. Cechami związanymi z tą formą organizacyjno-prawną są m.in. możliwość zrzeszania się oraz niestała liczba członków spółdzielni. Dla banków spółdzielczych, jak i SKOK-ów charakterystyczne jest również to, że gromadzony fundusz udziałowy zwiększa się głównie w wyniku składek członkowskich. Działalność gospodarcza tych instytucji jest prowadzona w interesie wszystkich członków. Do istotnych cech różnicujących przedstawione typy spółdzielni można zaliczyć to, że banki spółdzielcze, jak wskazuje na to nazwa, zaliczane są do banków, natomiast SKOK-i charakteryzowane są jako instytucje niebankowe. Banki spółdzielcze realizują kompleksowo zasadę „otwartych drzwi”. Oznacza to, że członkowie banków spółdzielczych nie muszą być ze sobą powiązani w żaden sposób, a oferta banków kierowana jest do szerokiego grona odbiorców. Spółdzielcze kasy oszczędnościowo-kredytowe natomiast stosują powyższą zasadę w ograniczonym stopniu, co oznacza, że członkowie SKOK-ów muszą być ze sobą powiązani w określony, organizacyjny lub zawodowy sposób. W przypadku instytucji pozabankowej, jej usługi skierowane są do znacznie mniejszej grupy osób, tj. tylko do jej członków. Dzięki temu ryzyko związane z nieodzyskaniem środków od odbiorców jest dużo mniejsze niż w przypadku banków spółdzielczych [Orzeszko 2014: 137-140].

\subsection{Podobieństwa i różnice między bankami spółdzielczymi a bankami komercyjnymi}

Podobieństwa jakie można zauważyć pomiędzy bankami spółdzielczymi a bankami komercyjnymi wynikają z przepisów prawnych. Zarówno banki w formie spółek akcyjnych, jak i banki spółdzielcze są określane mianem banków, przy czym spółdzielcze kasy oszczędnościowo-kredytowe definiowane są już jako instytucje niebankowe. Banki komercyjne oraz spółdzielcze spełniają podstawową rolę, jaką jest przyjmowanie środków pieniężnych od deponentów oraz udzielanie kredytów. Pośredniczą one w ten sposób między deponentami a kredytobiorcami [Marcinkowska 2013: 11].

Ze względu na to, że banki działają na rynku międzybankowym i podlegają prawu bankowemu są nadzorowane przez państwowe instytucje kontrolujące. Nadzór ten jest bardzo znaczącym elementem wpływającym na funkcjonowanie banków na rynku $\mathrm{z}$ uwagi na to, że banki przechowują pieniądze deponentów. Ponadto banki komercyjne i spółdzielcze są nastawione na ryzyko. Jest to nieunikniony proces, gdyż wynika ze specyfiki prowadzenia działalności bankowej. Wielkość przyjmowanego ryzyka przez banki jest uzależniona od wielu czynni- 
ków, np. rozmiarów posiadanych kapitałów własnych [Marcinkowska 2013: 17-18].

Banki komercyjne, jak i spółdzielcze są instytucjami zaufania publicznego, z czego wynika, że ich wspólnym celem jest utrzymanie jak największego grona odbiorców. Jest to bardzo ważne, gdyż klienci, którzy utracą zaufanie do konkretnej instytucji bankowej, mogą utracić je również do całego systemu bankowego. Wynika z tego, że najważniejszą grupą interesariuszy dla banków komercyjnych, jak i spółdzielczych są ich klienci. Zarówno deponenci, jak i kredytobiorcy w największym stopniu wpływają na funkcjonowanie banków oraz generowanie przez nie zysków [Marcinkowska 2013: 30].

Podstawowym czynnikiem różnicującym banki spółdzielcze oraz komercyjne jest to, że banki komercyjne za swój najważniejszy cel działania uważają uzyskiwanie oraz gromadzenie środków finansowych, by następnie ulokować je w produkty bankowe, które będą generować zamierzone zyski. Akcjonariusze banków komercyjnych również otrzymują benefity dzięki uzyskiwaniu zadowalających zysków oraz umocnieniu pozycji banku na rynku międzybankowym. Banki spółdzielcze natomiast, nie koncentrują się w tak dużym stopniu jak banki komercyjne na osiąganiu zysków, lecz skupiają się w głównej mierze na interesie swoich klientów [Cichorska 2013: 148]. Odmienne cele dwóch rodzajów banków wynikają z ich różnych form własności. W bankach w formie spółdzielni właścicielami są członkowie spółdzielni, czyli udziałowcy, natomiast w bankach działających jako spółki akcyjne właścicielami są akcjonariusze. Banki komercyjne w związku z podstawowym celem maksymalizacji zysków przez akcjonariuszy skutecznie udoskonalają swoją ofertę wprowadzając substytuty oraz komplementarne produkty bankowe, co pomaga im osiągnąc dodatkowe źródło finansowania [Wąsowski 2004: 31].

Kolejną, ważną różnicą zauważalną w funkcjonowaniu banków w formie spółek akcyjnych oraz banków spółdzielczych jest wielkość gromadzonych przez banki funduszy własnych. Banki spółdzielcze muszą zgromadzić minimalny kapitał w wysokości $1 \mathrm{mln}$ euro, by móc funkcjonować na rynku. Jeżeli chodzi o banki komercyjne wymagane fundusze własne wynoszą $5 \mathrm{mln}$ euro. W przypadku skumulowania przez bank spółdzielczy kwoty co najmniej $5 \mathrm{mln}$ euro, bank ten nie musi zrzeszać się z wybraną instytucją zrzeszającą, ale może funkcjonować $\mathrm{w}$ indywidualnym zakresie, podobnie jak banki prowadzące swoją działalność $\mathrm{w}$ formie spółki akcyjnej. Jeżeli bank spółdzielczy nie zgromadzi kapitału na poziomie $5 \mathrm{mln}$ euro musi działać w ramach zrzeszenia. Biorąc pod uwagę to, że banki komercyjne są dużo większe od banków spółdzielczych ich oferta znacząco różni się w zakresie wyspecjalizowanych usług, których często nie oferują banki spółdzielcze lub oferują w znacznie ograniczonym zakresie. Związane jest to również z mniejszym gronem odbiorców, pochodzących głównie z mniejszych miejscowości [Nastarowicz 2017: 17]. 
Tabela 1. Porównanie banków spółdzielczych ze SKOK-mi i bankami komercyjnymi

\begin{tabular}{|c|c|c|c|}
\hline $\begin{array}{l}\text { Wybrane ele- } \\
\text { menty porów- } \\
\text { nawcze }\end{array}$ & Banki spółdzielcze & SKOK-i & Banki komercyjne \\
\hline Typ instytucji & Bank & Instytucja niebankowa & Bank \\
\hline Cel działania & $\begin{array}{l}\text { Zaspokajanie potrzeb } \\
\text { członków spółdzielni oraz } \\
\text { społeczności lokalnych }\end{array}$ & $\begin{array}{l}\text { Zaspokajanie potrzeb człon- } \\
\text { ków SKOK-ów }\end{array}$ & $\begin{array}{l}\text { Maksymalizacja } \\
\text { zysków }\end{array}$ \\
\hline $\begin{array}{l}\text { Przepisy praw- } \\
\text { ne regulujące } \\
\text { funkcjonowa- } \\
\text { nie instytucji }\end{array}$ & $\begin{array}{l}\text { Prawo Bankowe, Ustawa } \\
\text { o funkcjonowaniu banków } \\
\text { spółdzielczych, Prawo } \\
\text { spółdzielcze }\end{array}$ & $\begin{array}{l}\text { Ustawa o spółdzielczych } \\
\text { kasach oszczędnościowo- } \\
\text { kredytowych, Prawo spół- } \\
\text { dzielcze }\end{array}$ & $\begin{array}{l}\text { Prawo Bankowe, } \\
\text { Kodeks spółek } \\
\text { handlowych }\end{array}$ \\
\hline $\begin{array}{l}\text { Wymagane } \\
\text { fundusze wła- } \\
\text { sne }\end{array}$ & Co najmniej $1 \mathrm{mln}$ euro & $\begin{array}{l}\text { Nie regulowane do roku } \\
2012 \text {, od } 2013 \text { roku wyma- } \\
\text { gane fundusze własne na } \\
\text { poziomie co najmniej 5\% } \\
\text { aktywów }\end{array}$ & $\begin{array}{l}\text { Co najmniej } 5 \mathrm{mln} \\
\text { euro }\end{array}$ \\
\hline $\begin{array}{l}\text { Nadzór nad } \\
\text { instytucją }\end{array}$ & KNF & $\begin{array}{l}\text { Do roku } 2012 \text { Krajowa } \\
\text { Spółdzielcza Kasa Oszczęd- } \\
\text { nościowo-Kredytowa, od } \\
2013 \text { roku KNF }\end{array}$ & $\mathrm{KNF}$ \\
\hline $\begin{array}{l}\text { Typ organiza- } \\
\text { cyjny }\end{array}$ & $\begin{array}{l}\text { Banki zrzeszające się } \\
\text { w Banku Polskiej Spół- } \\
\text { dzielczości (BPS S.A.) lub } \\
\text { w Spółdzielczej Grupie } \\
\text { Bankowej (SGB Bank S.A.) }\end{array}$ & $\begin{array}{l}\text { SKOK-i zrzeszające się } \\
\text { w Kasie Krajowej SKOK }\end{array}$ & $\begin{array}{l}\text { Indywidualnie } \\
\text { ustalany dla każde- } \\
\text { go banku }\end{array}$ \\
\hline $\begin{array}{l}\text { Forma organi- } \\
\text { zacyjno- } \\
\text {-prawna }\end{array}$ & Spółdzielnia & Spółdzielnia & Spółka akcyjna \\
\hline Właściciele & $\begin{array}{l}\text { Członkowie spółdzielni- } \\
\text { nie muszą być ze sobą } \\
\text { powiązani w żaden sposób }\end{array}$ & $\begin{array}{l}\text { Członkowie spółdzielni- } \\
\text { muszą być ze sobą powiąza- } \\
\text { ni w określony sposób, np. } \\
\text { zawodowo, organizacyjnie }\end{array}$ & Akcjonariusze \\
\hline
\end{tabular}

Źródło: opracowanie na podstawie Kil [2018: 137].

Jeżeli chodzi o wykonywanie czynności bankowych przez banki spółdzielcze i komercyjne warto zauważyć, że wybrane czynności bankowe sprawowane są przez banki spółdzielcze tylko w przypadku uzyskania pozwolenia od banku, z którym są zrzeszone. Te same czynności bankowe, banki komercyjne mogą wykonywać zgodnie $\mathrm{z}$ regulacjami prawnymi. Banki spółdzielcze działające w ramach zrzeszeń zabezpieczają się w ten sposób przed utratą klientów, bowiem osoby zainteresowane określonymi produktami bankowymi bądź usługami, którymi bank spółdzielczy stricte nie dysponuje, nie są zmuszeni do korzystania z usług banków komercyjnych [Nastarowicz 2017: 17]. 


\section{DANE STATYSTYCZNE DOTYCZĄCE BANKÓW SPÓŁDZIELCZYCH, BANKÓW KOMERCYJNYCH ORAZ KAS OSZCZĘDNOŚCIOWO-KREDYTOWYCH}

\subsection{Liczba instytucji}

Na wykresie 1 pokazano jak kształtowała się liczebność instytucji bankowych oraz spółdzielczych kas oszczędnościowo-kredytowych na przestrzeni lat 2014 -2017 .

Z uwagi na dużą rozbieżność w liczebności poszczególnych instytucji finansowych, na lewej osi przedstawiono liczebność instytucji banków komercyjnych oraz spółdzielczych kas oszczędnościowo-kredytowych. Na prawej osi natomiast pokazano liczbę banków spółdzielczych.

Zauważalna jest tendencja malejąca w przypadku wszystkich badanych instytucji finansowych w badanych latach.

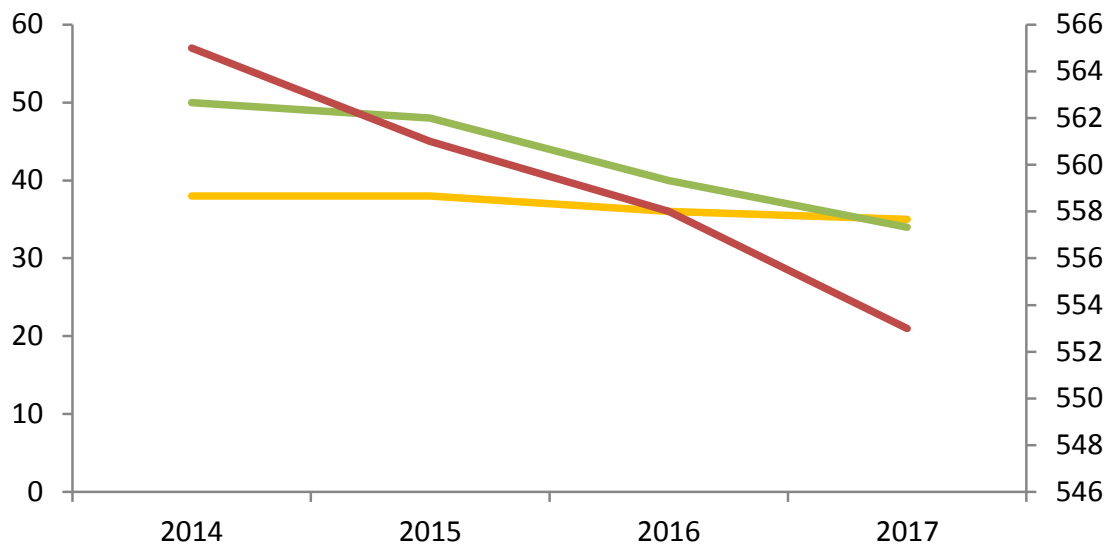

Banki komercyjne(lewa oś) —SKOK-i(lewa oś) —Banki spółdzielcze(prawa oś)

Wykres 1. Liczba banków spółdzielczych, komercyjnych oraz SKOK w latach 2014-2017.

Źródło: opracowanie na podstawie danych Komisji Nadzoru Finansowego; danych miesięcznych sektora bankowego za grudzień 2018 r. oraz raportów o sytuacji spółdzielczych kas oszczędnościowo-kredytowych w latach 2015-2017.

Na koniec 2017 roku działało 553 banków spółdzielczych, 352 z nich było zrzeszonych w BPS S.A. w Warszawie, a 199 w SGB-Banku S.A. w Poznaniu. Poza nimi działały banki niezrzeszone - Krakowski Bank Spółdzielczy oraz Bank Spółdzielczy w Brodnicy. Liczba banków spółdzielczych w 2017, w porównaniu do roku 2014, zmniejszyła się o 12. Jeżeli chodzi o banki komercyjne 
i SKOK-i w 2017 roku ich liczba ukształtowała się na porównywalnym poziomie tj. odpowiednio 35 i 34. Było to o 3 banki komercyjne i 16 SKOK-ów mniej niż w 2014 roku [Informacja o sytuacji banków spółdzielczych i zrzeszających w 2017 r., 2018: 3; Dane miesięczne sektora bankowego..., dostęp 28.02.2019].

\subsection{Liczba placówek}

Na wykresie 2 ukazano w jaki sposób zmieniała się liczba oddziałów i innych placówek instytucji o charakterze spółdzielni oraz banków komercyjnych w latach 2014-2017.

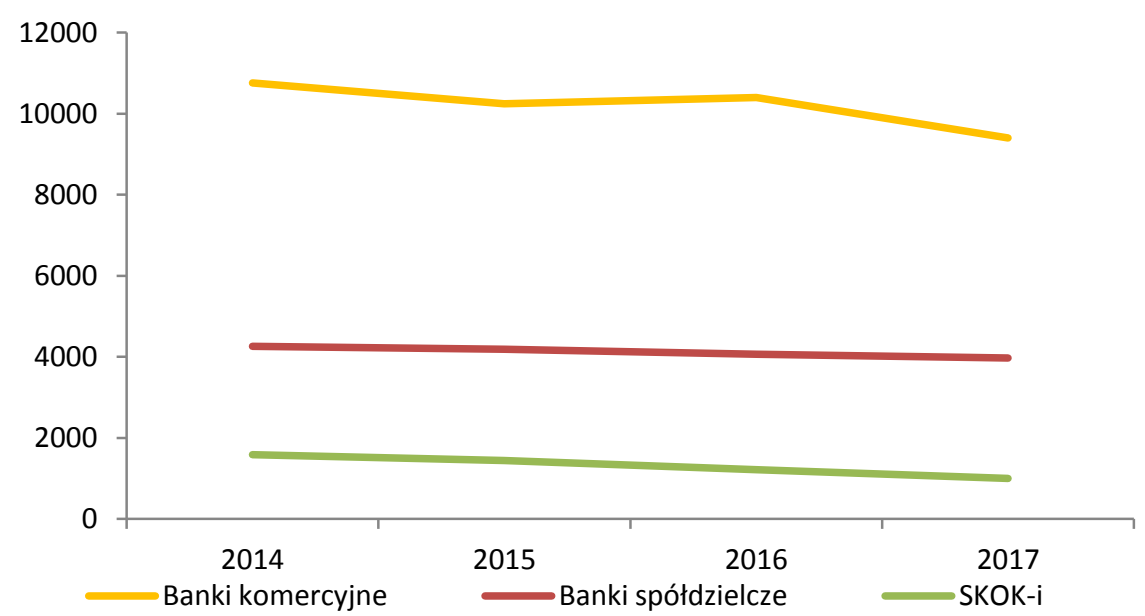

Wykres 2. Liczba oddziałów i innych placówek banków spółdzielczych, komercyjnych oraz SKOK w latach 2014-2017

Źródło: opracowanie na podstawie danych statystycznych Głównego Urzędu Statystycznego.

Liczba placówek banków komercyjnych w 2014 roku wynosiła 10760. W roku 2016, w porównaniu do poprzedniego, odnotowano wzrost tej wartości o $1,5 \%$, natomiast $\mathrm{w}$ roku $2017 \mathrm{w}$ porównaniu do 2016 zauważono spadek o 10,6\%. Liczba placówek banków spółdzielczych w latach 2014-2017 sukcesywnie spadała, aż do wartości 3969 . Było to o 296 mniej placówek niż w roku 2014. W przypadku SKOK-ów, liczba ich placówek w analizowanych latach zmniejszyła się o 581 [Monitoring banków 2017, 2018: 41-42; Wyniki finansowe spółdzielczych kas oszczędnościowo-kredytowych w latach 2014-2017]. 


\subsection{Zatrudnienie}

Poniżej zaprezentowano liczbę osób podejmujących pracę w instytucjach bankowych oraz spółdzielczych kasach oszczędnościowo-kredytowych w przedziale czasowym 2014-2017. Zauważalny jest spadek pracowników tych instytucji w badanych latach.

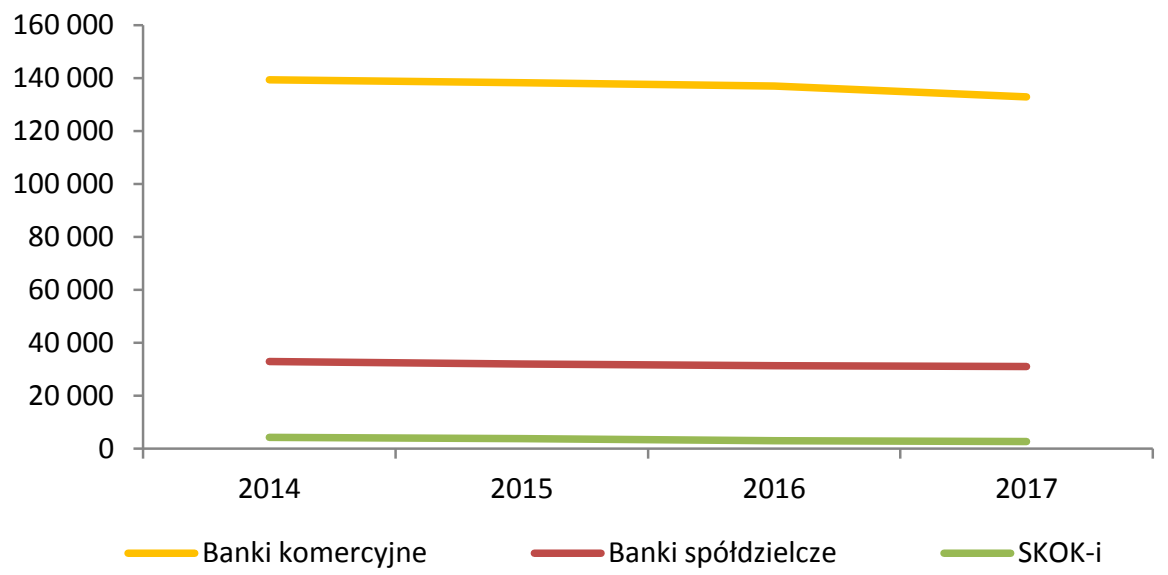

Wykres 3. Liczba zatrudnionych w bankach spółdzielczych, komercyjnych oraz SKOK-ach w latach 2014-2017

Źródło: opracowanie na podstawie danych statystycznych Głównego Urzędu Statystycznego.

W bankach komercyjnych w 2017 roku w porównaniu do 2016 zatrudnienie zmniejszyło się o około 3\%, w bankach spółdzielczych o $1 \%$, natomiast w SKOK aż o 15\%. Średnio 14 pracowników przypada na jedną placówkę banku komercyjnego, 7 na jedną placówkę banku spółdzielczego i 2 na jedną placówkę SKOK-u [Monitoring banków 2017, 2018: 43; Wyniki finansowe spółdzielczych kas oszczędnościowo-kredytowych w latach 2014-2017: 1].

\section{ANALIZA ZADOWOLENIA KLIENTÓW BANKÓW SPÓŁDZIELCZYCH W PORÓWNANIU DO BANKÓW KOMERCYJNYCH I SPÓŁDZIELCZYCH KAS OSZCZĘDNOŚCIOWO- -KREDYTOWYCH}

W obecnych czasach na rynku usług finansowych dochodzi do znaczącej konkurencji między bankami spółdzielczymi, komercyjnymi oraz spółdzielczymi kasami oszczędnościowo-kredytowymi. Instytucje te działając w tym samym obszarze rynku, muszą się czymś wyróżniać, by wypracować sobie konkurencyjną 
pozycję. W przeciwnym razie, klienci będą wybierać instytucje finansowe w sposób przypadkowy. W celu pozyskania jak największej grupy klientów instytucje opracowują swoją misję i strategię działania [Staszyńska 2013: 67].

Najważniejszym celem realizowanej strategii jest osiągnięcie zadowolenia klienta. Zadowolenie to może być całkowite lub częściowe. Zadowolenie klienta $\mathrm{z}$ usług oferowanych przez wybraną instytucję finansową jest tak ważnym aspektem, gdyż może spowodować, że klient ponownie skorzysta z usług tej samej instytucji. Na podstawie porównania oczekiwań z rzeczywistością oszacowuje się poziom zadowolenia klienta. Wpływa na to doświadczenie konsumenta oraz jego znajomość sytuacji na rynku. Tak więc, przykładowo świadomy konsument znający wysokość opłat i prowizji za prowadzenie rachunku w swojej instytucji finansowej, będzie skłonny ją zmienić, jeśli dowie się o bardziej korzystnej ofercie innej instytucji. Na zadowolenie klienta nie będzie wpływać tylko jakość produktu bankowego, ale również jakość sposobu sprzedaży (np. miła obsługa w placówce) [Staszyńska 2013: 186].

W celu poznania oczekiwań klientów oraz ich poziomu zadowolenia z usług oferowanych przez instytucje finansowe, takie jak banki spółdzielcze, banki komercyjne i spółdzielcze kasy oszczędnościowo-kredytowe, autorka artykułu przeprowadziła badanie wśród grupy respondentów. Badanie pozwoliło określić stopień konkurencyjności banków spółdzielczych w porównaniu do wymienionych wyżej instytucji finansowych. Kwestionariusz ankiety „Korzystanie z usług finansowych a zadowolenie klientów" składa się z 18 pytań dotyczących tematyki badania oraz z 6 pytań metryczkowych. Pytania tematyczne są zamknięte i półotwarte. Poruszają następujące zagadnienia:

- zakres korzystania z usług finansowych,

- ocena obszarów funkcjonowania instytucji finansowych,

- aspekty funkcjonalności bankowości elektronicznej i mobilnej,

- wiedza z zakresu akcji promocyjnych i marketingowych.

W lutym 2019 r. przeprowadzono przez autorkę artykułu badanie ilościowe na temat zadowolenia klientów z usług finansowych oferowanych przez banki spółdzielcze, banki komercyjne oraz spółdzielcze kasy oszczędnościowo-kredytowe. W przeprowadzonym badaniu wykorzystano metodę CAWI, czyli Computer Assisted Web Interviewing. Wykorzystany system umożliwił przeprowadzenie badania $\mathrm{w}$ formie ankiety, którą respondenci wypełniali za pośrednictwem Internetu. Każda udzielona przez ankietowanego odpowiedź była zapisana w automatycznie tworzonej bazie danych. Ułatwiło to tworzenie kwestionariusza oraz późniejszą analizę [Sobocińska 2005: 200].

Zasięg przeprowadzonego badania ankietowego był ograniczony ze względu na zbyt liczną zbiorowość do przebadania (osoby korzystające oraz nie korzystające $\mathrm{z}$ usług finansowych). Dobór respondentów odbył się w sposób nielosowy. Zastosowano metodę doboru proporcjonalnego. Oznacza to, że dobierając próbę 
badawczą starano się wyszukać podobną liczbę respondentów w przedziale wiekowym 18-25, 26-37, 38-49 oraz 50 lat i powyżej. W celu szybszego i skuteczniejszego dotarcia do badanych środowisk zastosowano dwie metody doboru próby (metoda opierająca się na dystrybucji ankiet internetowych za pośrednictwem portalu społecznościowego Facebook oraz metoda kuli śnieżnej przy użyciu drogi mailowej, poprzez rozsyłanie linka do ankiety) [Marak 2005: 115].

Celem przeprowadzonego badania jest weryfikacja hipotezy badawczej mówiącej o tym, że osoby korzystające z usług banków spółdzielczych są bardziej zadowolone niż osoby korzystające $\mathrm{z}$ oferty banków komercyjnych oraz spółdzielczych kas oszczędnościowo-kredytowych. Zadowolenie klientów zostanie zbadane w oparciu o wybrane czynniki.

\subsection{Analiza danych empirycznych}

W przeprowadzonym badaniu ankietowym przebadano 100 respondentów. Struktura płci ankietowanych kształtuje się na podobnym poziomie, z niewielką przewagą kobiet, które stanowią 57\% wszystkich badanych. Jeżeli chodzi o wiek respondentów, wszystkie badane grupy wiekowe (tj. 18-25, 26-37, 38-49, 50 lat i więcej) stanowią taki sam udział (25\%).

W przeprowadzonej ankiecie zbadano m.in. jak wybrane obszary funkcjonowania banków spółdzielczych, banków komercyjnych oraz SKOK-ów oceniają ich klienci. Wyniki pokazano na dwóch wykresach 4 i 5.

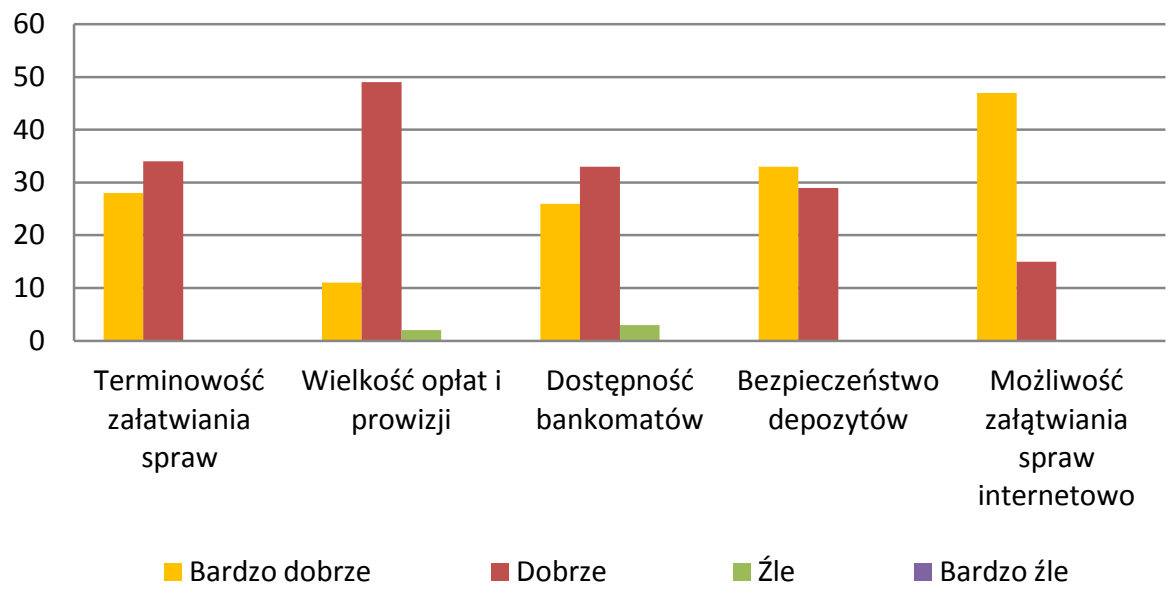

Wykres 4. Ocena wybranych obszarów funkcjonowania banku komercyjnego

Źródło: opracowane na podstawie badania ankietowego autorki artykułu. 
Jeżeli chodzi o ocenę przedstawionych już obszarów funkcjonowania, w bankach komercyjnych terminowość załatwiania spraw postrzegana jest dobrze przez 55\% respondentów oraz bardzo dobrze przez $45 \%$ klientów. Zdecydowana większość ankietowanych, tj.79\%, deklaruje, że wielkość opłat i prowizji jest na dobrym poziomie, $18 \%$ na bardzo dobrym, a jedynie $3 \%$ twierdzi, że koszty są za duże. Kolejnym badanym obszarem jest dostępność bankomatów banków komercyjnych, która jest oceniana w 53\% dobrze, w $42 \%$ bardzo dobrze, a tylko w 5\% źle. 53\% ankietowanych jest pewnych, że ich depozyty są bezpieczne, natomiast $47 \%$ ocenia bezpieczeństwo w stopniu dobrym. Najlepiej oceniana jest możliwość załatwiania spraw internetowo. Aż $76 \%$ klientów banków komercyjnych ocenia ją bardzo dobrze, natomiast $24 \%$ dobrze.

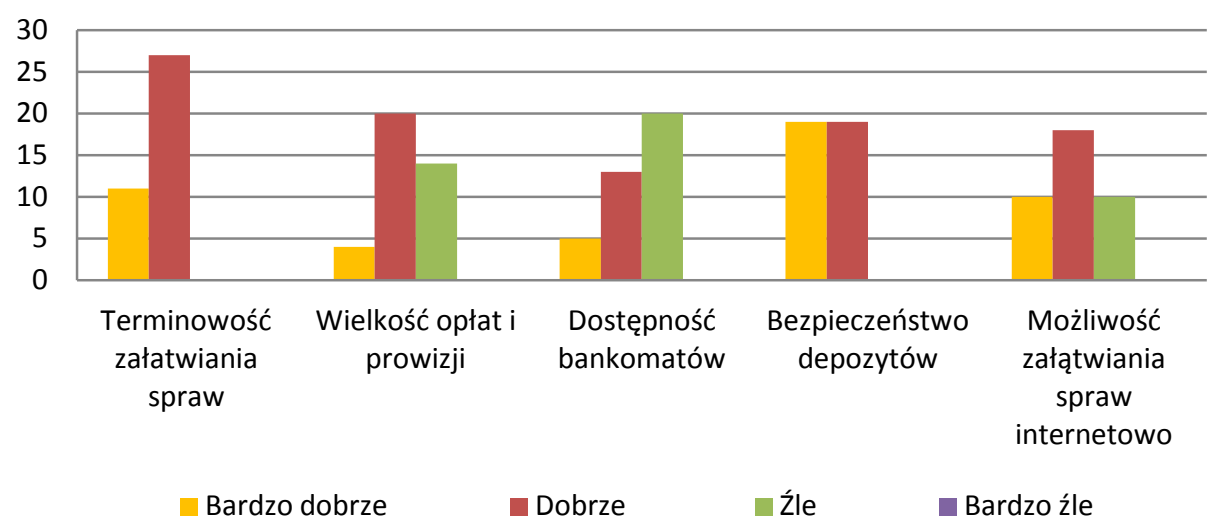

Wykres 5. Ocena wybranych obszarów funkcjonowania banku spółdzielczego

Źródło: opracowane na podstawie badania ankietowego autorki artykułu.

W przypadku banków spółdzielczych terminowość załatwiania spraw w tego typu instytucjach oceniana jest dobrze przez $71 \%$ badanych oraz bardzo dobrze przez $29 \%$ ankietowanych. Jeżeli chodzi o wielkość opłat i prowizji nieco ponad połowa ankietowanych uważa ją za odpowiednią, $37 \%$ wskazuje na to, że koszty są zbyt wysokie, a jednie $10 \%$ jest bardzo zadowolona $\mathrm{z}$ ich poziomu. W bankach komercyjnych jedynie 3\% uważa koszty opłat i prowizji za zbyt wysokie. Dostępność bankomatów banków spółdzielczych jest oceniana najgorzej ze wszystkich pięciu obszarów. Ponad połowa respondentów (53\%) ocenia źle tą funkcjonalność, $34 \%$ dobrze, a jedynie 13\% bardzo dobrze. W bankach komercyjnych $5 \%$ ocenia źle tą funkcjonalność. Kolejnym badanym obszarem było bezpieczeństwo depozytów. 50\% ankietowanych bardzo dobrze ocenia bezpieczeństwo swoich środków. Ostatnim z wziętych pod uwagę obszarów 
funkcjonalności instytucji jest możliwość załatwiania spraw za pomocą Internetu. Prawie połowa ankietowanych ocenia taką możliwość dobrze, $26 \%$ bardzo dobrze, jak i również $26 \%$ źle. W bankach komercyjnych wszyscy badani oceniają mobilność banku dobrze lub bardzo dobrze. W przypadku SKOK-u respondent ocenia wszystkie funkcjonalności w stopniu dobrym.

Zapytano również respondentów o stopień ich zadowolenia $\mathrm{z}$ instytucji finansowej, z której usług korzystają. Swoje zdanie musieli wyrazić za pomocą skali od 1 do 5 , gdzie 1 oznaczało najmniej zadowolony, a 5 najbardziej zadowolony.

Tabela 2. Stopień zadowolenia respondentów z wybranej instytucji finansowej

\begin{tabular}{|c|c|c|c|}
\hline $\begin{array}{c}\text { Stopień zadowolenia } \\
\text { z instytucji finansowej }\end{array}$ & $\begin{array}{c}\text { Bank spółdzielczy } \\
\text { (liczba badanych) }\end{array}$ & $\begin{array}{c}\text { Bank komercyjny } \\
\text { (liczba badanych) }\end{array}$ & $\begin{array}{c}\text { SKOK } \\
\text { (liczba badanych) }\end{array}$ \\
\hline 1 & 0 & 0 & 0 \\
\hline 2 & 1 & 0 & 0 \\
\hline 3 & 14 & 4 & 1 \\
\hline 4 & 18 & 34 & 0 \\
\hline 5 & 5 & 24 & 0 \\
\hline
\end{tabular}

Źródło: opracowane na podstawie badania ankietowego autorki artykułu.

W przypadku banków spółdzielczych $47 \%$ ankietowanych oceniło swoje zadowolenie na $4,37 \%$ na $3,13 \%$ na 5 , a niespełna $3 \%$ na 2 . W bankach komercyjnych zadowolenie ich klientów z działania instytucji było na wyższym poziomie niż w przypadku klientów banków spółdzielczych. Około 55\% badanych oceniło stopień zadowolenia na $4,39 \%$ na 5 , a jedynie $6 \%$ oceniło działanie instytucji na 4. Klient SKOK-u ocenił jej działanie na 3.

Zbadano również czynniki, które w największym stopniu mogą przyczynić się do zmiany instytucji finansowej na inną przez klientów.

W bankach spółdzielczych ankietowani najczęściej podawali następujące odpowiedzi: bardziej rozbudowana oferta usług finansowych, tj. $32 \%$, niższe koszty opłat i prowizji oraz lepsza dostępność bankomatów, tj. 16\%. Lepsza dostępność placówek i bardziej profesjonalna obsługa miały znikomy udział. Jedynie $12 \%$ ankietowanych nie widzi potrzeby zmian instytucji na inną. Odmienna sytuacja jest w przypadku banków komercyjnych, gdyż ponad połowa respondentów jest zadowolona $\mathrm{z}$ funkcjonowania instytucji. Pozostali ankietowani wskazywali takie odpowiedzi jak niższe koszty opłat i prowizji $22 \%$, bardziej rozbudowana oferta banku. Każdy z pozostałych czynników (lepsza dostępność bankomatów, placówek, profesjonalna obsługa) stanowił poniżej $10 \%$ odpowiedzi respondentów. 


\section{Co skłoniłoby Pana/Panią do zmiany instytucji finansowej na inną?}

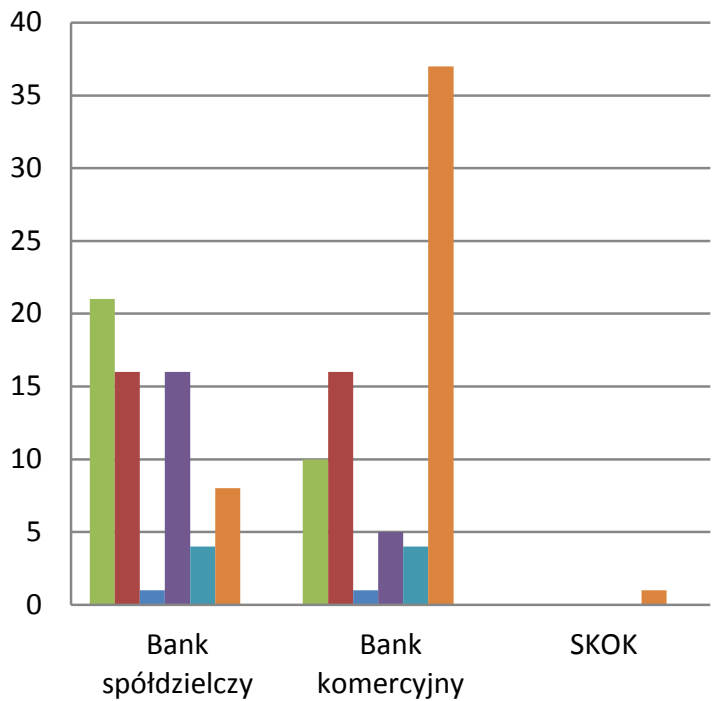

Bardziej rozbudowana oferta usług finansowych

Niższe koszty opłat i prowizji

Bardziej profesjonalna obsługa

Lepsza dostępność bankomatów

lepsza dostępność placówek

Jestem zadowolony/a z funkcjonowania instytucji. Nie widzę potrzeby zmian

Wykres 6. Czynniki wpływające na zmianę instytucji finansowej na inną

Źródło: opracowane na podstawie badania ankietowego autorki artykułu.

\section{WNIOSKI Z BADAŃ}

Z przeprowadzonego badania wynika, że zdecydowana większość tj. 93\% konsumentów korzysta $z$ usług finansowych. Wśród badanej grupy respondentów przeważająca część osób korzystających z usług finansowych jest klientelą banków komercyjnych, a znacznie mniejsza banków spółdzielczych. Tylko jeden ankietowany jest klientem SKOK-u. Przy wstępnej analizie można zatem stwierdzić, że to banki komercyjne są najbardziej konkurencyjnymi instytucjami finansowymi. Jednak należy pamiętać, że oddziałów i placówek banków komercyjnych jest zdecydowanie więcej niż banków spółdzielczych oraz SKOK-ów, co może powodować taką strukturę badanych.

Część klientów banków spółdzielczych jest widocznie niezadowolona z dostępności bankomatów, wielkości opłat i prowizji oraz możliwości załatwiania spraw internetowo. Te same obszary funkcjonowania zdecydowana większość klientów banków komercyjnych ocenia jako dobre lub bardzo dobre. Klienci banków spółdzielczych najczęściej oceniali swoje zadowolenie z usług instytucji 
na niższym poziomie w porównaniu do klientów banków komercyjnych. Podobna liczba osób korzystających z usług bankowości spółdzielczej była zadowolona $\mathrm{z}$ funkcjonowania swojej instytucji jak również niezadowolona. W przypadku banków komercyjnych zdecydowana większość badanych zawsze była zadowolona z usług swojego banku. Większa część klientów banków spółdzielczych poleciłaby swoją instytucję finansową, jednak jest ich aż o 28 punktów procentowych mniej w porównaniu do klientów banków komercyjnych. Większą konkurencyjność banków komercyjnych potwierdza również fakt, że dominująca część ich klientów jest zadowolona $\mathrm{z}$ działania instytucji i nie widzi potrzeby zmiany na inną. Inna sytuacja jest w przypadku banków w formie spółdzielni, gdyż ich klienci wskazywali, że mogliby zmienić swoją instytucję z uwagi na za słabo rozbudowaną ofertę bankową, zbyt wysokie koszty oraz zbyt niską dostępność bankomatów.

Aż 68\% osób korzystających z usług banków spółdzielczych nie jest świadoma podejmowanych działań promocyjnych przez swoją instytucję. Przekłada się to na wysoki odsetek osób niekorzystających z promocji. Banki komercyjne natomiast skupiając się $\mathrm{w}$ dużym stopniu na akcjach marketingowych pozyskują klientów zainteresowanych takimi okazjami. Wysoki procent klientów banków spółdzielczych jak i komercyjnych korzysta z bankowości elektronicznej/mobilnej za pomocą Internetu. Powoduje to coraz rzadszą potrzebę odwiedzania placówek. Można zatem stwierdzić, że zakres czynności, które można załatwić samemu przez Internet jest ważnym czynnikiem konkurencyjnym, który wykorzystują banki komercyjne, zachęcając do nowych rozwiązań mobilnych. Nie każdy konsument jest zadowolony z reklam, prawie 1/4 konsumentów wskazuje negatywny stosunek do takiej formy promocji. Należy jednak pamiętać, że nadal reklamy skutkują pozyskaniem nowych klientów.

O dużej konkurencyjności banków komercyjnych świadczy również struktura wiekowa ich klientów. Młodsze pokolenie znacznie częściej decyduje się na skorzystanie z usług tych instytucji finansowych. Banki spółdzielcze bazując na starszych odbiorcach mogą być zagrożone w przyszłości spadającą liczbą klientów.

Podsumowując, klienci banków komercyjnych są dużo bardziej zadowoleni z działania swojej instytucji niż klienci banków spółdzielczych. Potwierdza to, że banki komercyjne są bardziej konkurencyjne, chociażby ze względów kosztowych i technologicznych. Klienci banków spółdzielczych w większości zostali zachęceni do wyboru swojej instytucji dzięki swoim bliskim. Może to świadczyć o tym, że banki spółdzielcze w pełni wykorzystają swój potencjał lokalny. Duże znaczenie w bankach lokalnych mają produkty oszczędnościowe, to właśnie na nie klienci banków spółdzielczych decydują się dużo częściej niż klienci banków komercyjnych. W celu poprawy konkurencyjności banki spółdzielcze powinny skupić się na rozszerzeniu sieci bankomatów, mniejszych opłatach i prowizjach oraz szeroko pojętej technologii informatycznej. 


\section{PODSUMOWANIE}

Bankowość spółdzielcza, której dotyczy niniejszy artykuł, została przedstawiona na wielu płaszczyznach. Miało to na celu pokazanie innego, aktualnego spojrzenia na ten sektor, z punktu widzenia obywateli.

$\mathrm{W}$ artykule, autorka realizowała przedstawione we wstepie cele poprzez analizę i interpretacje literatury, dotyczącej szeroko pojętej bankowości spółdzielczej. Ponadto autorka korzystała z publikacji statystycznych, udostępnionych na stronach GUS oraz KNF. Pozwoliło to na porównanie danych jakościowych i ilościowych sektora bankowości spółdzielczej, komercyjnej oraz SKOK-ów. Podstawowym narzędziem służącym do zbadania konkurencyjności instytucji finansowych z perspektywy zadowolenia klientów był kwestionariusz ankiety.

W artykule skupiono się na weryfikacji konkurencyjności z punktu widzenia zadowolenia klientów. Pozwoliło to na zweryfikowanie poprawności hipotezy badawczej mówiącej o tym że, najbardziej konkurencyjnymi instytucjami finansowymi, z punktu widzenia satysfakcji klientów, spośród banków spółdzielczych, banków komercyjnych i SKOK-ów są banki spółdzielcze.

$\mathrm{Na}$ weryfikację hipotezy badawczej w największym stopniu wpłynęło to, że $53 \%$ klientów banków spółdzielczych widocznie wskazywało na potrzebę bardziej rozbudowanej sieci bankomatów, 37\% klientów zadeklarowało problem zbyt wysokich opłat i prowizji, natomiast $26 \%$ badanych wskazało, że potrzebuje lepiej dostępnych i rozbudowanych rozwiązań elektronicznych. W bankach komercyjnych sytuacja ta kształtowała się o wiele bardziej korzystnie. Jedynie 5\% klientów uważało, że liczba dostępnych bankomatów jest zbyt niska, 3\% badanych stwierdziło, że wysokość opłat i prowizji jest za wysoka. Wszyscy przebadani klienci banków komercyjnych uznali, że bankowość elektroniczna jest na odpowiednim poziomie.

Na podstawie badania stwierdzono, że klienci banków spółdzielczych nie są przywiązani kluczowo do swojej instytucji finansowej, pomimo dostrzegania atutów lokalności. Jedynie $20 \%$ klientów banków spółdzielczych nie widzi konieczności zmiany swojej instytucji na inną, w przypadku banków komercyjnych aż $60 \%$ ich klientów nie widzi potrzeby zmian (71\% klientów banków spółdzielczych oraz $98 \%$ klientów banków komercyjnych poleciłoby swoją instytucję finansową znajomym). Badanie pokazało również, że SKOK-i nie są dużą konkurencją dla sektora banków spółdzielczych, gdyż tylko 1 na 100 respondentów korzysta $\mathrm{z}$ usług tego typu instytucji. Klienci banków spółdzielczych zapytani o określenie swojego zadowolenia z instytucji w 5-stopniowej skali, w $61 \%$ ocenili ją na 4 lub 5. W przypadku banków komercyjnych, aż 94\% klientów oceniło swoje zadowolenie również na poziomie 4 lub 5. 
Powyższe wnioski dały podstawę do odrzucenia hipotezy badawczej. Dalsze badania mogłyby być podstawą do poprawy konkurencyjności banków spółdzielczych w przyszłości.

\section{BIBLIOGRAFIA}

Cichorska J., 2013, Kierunki zmian aktywności wspótczesnego banku, „Zeszyty Naukowe Wydziałowe Uniwersytetu Ekonomicznego w Katowicach. Studia Ekonomiczne Innowacje w Bankowości i Finansach", nr 173, t.1.

Dane miesięczne sektora bankowego, Komisja Nadzoru Finansowego, https://www.knf.gov.pl/ ?articleId=56224\&p_id=18 [dostęp 28.02.2019].

Dyrektywa Parlamentu Europejskiego i Rady 2013/36/UE z 26 czerwca 2013 roku w sprawie warunków dopuszczenia instytucji kredytowych do działalności oraz nadzoru ostrożnościowego nad instytucjami kredytowymi i firmami inwestycyjnymi.

Informacja o sytuacji banków spółdzielczych i zrzeszających w 2017 r., 2018, Komisja Nadzoru Finansowego, Warszawa

Informacja o sytuacji spółdzielczych kas oszczędnościowo-kredytowych w 2017 r., Komisja Nadzoru Finansowego.

Informacja o sytuacji spółdzielczych kas oszczędnościowo-kredytowych w III kwartale 2018 r., Komisja Nadzoru Finansowego.

Kil K., 2018, Stabilność finansowa banków spółdzielczych w Polsce w świetle pokryzysowych zmian regulacyjnych, Wydawnictwo Poltext, Warszawa.

Komunikat dot. ustawy o kredycie hipotecznym nad pośrednikami kredytu hipotecznego i agentami, KNF 2017.

Komunikat Urzędu Komisji Nadzoru Finansowego w sprawie nowych regulacji dot. komitetów audytu, 2017.

Marak J., 2005, Wykorzystanie metod ankietowych w badaniu zachowań podmiotów rynku, [w:] K. Mazurek-Łopacińska (red.), Badania Marketingowe Teoria i Praktyka, Wydawnictwo Naukowe PWN, Warszawa.

Marcinkowska M., 2013, Wartość banku. Kreowanie wartości i pomiar wyników działalności banku, Wydawnictwo Uniwersytetu Łódzkiego, Łódź.

Monitoring banków 2017, Główny Urząd Statystyczny, Warszawa 2018.

Nastarowicz E., 2017, Bankowość spółdzielcza - wyróżniki, misja, wartości, Wydawnictwo Centrum Prawa Bankowego i Informacji, Warszawa.

Orzeszko T., 2014, Banki spółdzielcze i spółdzielcze kasy oszczędnościowokredytowe w Polsce - podobieństwa oraz różnice, „Bezpieczny Bank”, $\mathrm{nr} 4(57)$.

Raport o sytuacji spółdzielczych kas oszczędnościowo-kredytowych na koniec 2015 roku, Komisja Nadzoru Finansowego.

Raport o sytuacji spółdzielczych kas oszczędnościowo-kredytowych na 31 grudnia 2016 roku, Komisja Nadzoru Finansowego.

Sobocińska M., 2005, Badania marketingowe przez Internet, [w:] K. Mazurek-Łopacińska (red.), Badania Marketingowe Teoria i Praktyka, Wydawnictwo Naukowe PWN, Warszawa.

Staszyńska K. M, 2013, Marka, Konsument, Badacz. Spotkania na rynku, Wydawnictwo Wolters Kluwer, Warszawa.

Ustawa z dnia 15 lutego 1992 r. o podatku dochodowym od osób prawnych, Dz.U. 2019, poz. 865. 
Ustawa z dnia 5 listopada 2009 r. o spółdzielczych kasach oszczędnościowo-kredytowych, Dz.U. 2018, poz. 2386.

Ustawa z dnia 16 września 1982 r. Prawo spółdzielcze, Dz.U. 2018, poz. 1285.

Wąsowski W., 2004, Ekonomika i finanse banku komercyjnego, Wydawnictwo Difin, Warszawa.

Wyniki finansowe banków w I półroczu 2018 r., Główny Urząd Statystyczny.

Wyniki finansowe spółdzielczych kas oszczędnościowo-kredytowych w 2017 r., Główny Urząd Statystyczny.

Wyniki finansowe spółdzielczych kas oszczędnościowo-kredytowych w 2016 r., Główny Urząd Statystyczny.

Wyniki finansowe spółdzielczych kas oszczędnościowo-kredytowych w 2015 r., Główny Urząd Statystyczny.

\title{
THE CHARACTER AND COMPETITIVENESS OF COOPERATIVE BANKS IN POLAND
}

\begin{abstract}
Cooperative banking is perceived mostly as a low-level traditional local banking. Therefore, the topic of the article was taken to show it is competitiveness in various areas. The aim of the article is to show the differences and similarities between cooperative banks and commercial banks and credit unions. Selected statistical data on these institutions was also presented. In addition, the author's intention was to examine the degree of competitiveness of cooperative banking. The author in the article was verifying the hypothesis that the most competitive among cooperative banks, commercial banks and credit unions are cooperative banks, which is assessed by customers in the perspective of their satisfaction. The research was conducted using a questionnaire. It showed that in the opinion of customers there are both prosperous areas of financial institutions and those that need improvement.
\end{abstract}

Keywords: cooperative bank, commercial bank, credit union, competitiveness, contentment, financial services. 